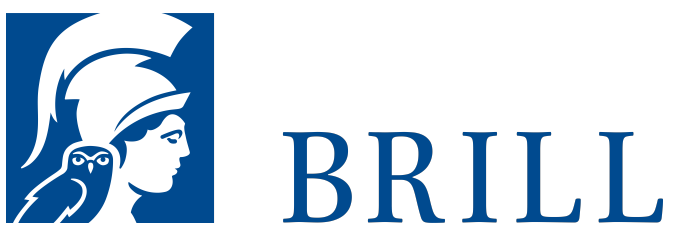

\title{
Konfessionalisierung und Staatsinteressen
}

\author{
Internationale Beziehungen 1559-166o
}

Author: Heinz Schilling

Der neue Band des Handbuchs der Geschichte der Internationalen Beziehungen behandelt in einer Kombination von struktur-, ereignis- und kulturgeschichtlichen Ansätzen die Entstehung des europäischen Staatensystems der Neuzeit in dem Jahrhundert zwischen dem Scheitern des Versuchs Karls V., die Staatenvielfalt Europas mit einem universalistischen Kaiserkonzept neu zu ordnen, und der Etablierung der ersten neuzeitlichen Staatenordnung durch die Friedensschlüsse in Westfalen, den Pyrenäen und Oliva zu Mitte des 17.

Jahrhunderts. Dem bewährten Aufbau des Handbuchs folgend, beschreibt ein erster Teil die Bedingungen von Außenpolitik und internationalen Beziehungen vor ihrer Monopolisierung durch den Staat. Gegliedert nach regionalen Mächtekreisen stellt der zweite Teil die einzelnen Akteure vor, mit einem Schwerpunkt auf den großen Antagonisten der Epoche: Osmanen, Habsburger resp. Spanien, England, Niederlande. Im dritten Teil werden die Ereignisse geschildert und in ihren struktur- wie kulturgeschichtlichen Bedingungen und Konsequenzen analysiert. Das Buch endet mit den großen Kriegen von 1618 bis 166o, die als Glaubens- und Staatenkriege begriffen werden, und mit einer Würdigung der diese Kriege beendenden Friedensverträge als neue europäische Mächteordnung auf der Basis souveräner, gegenüber den religiös-kirchlichen Kräften autonomer Partikularstaaten unter... See More

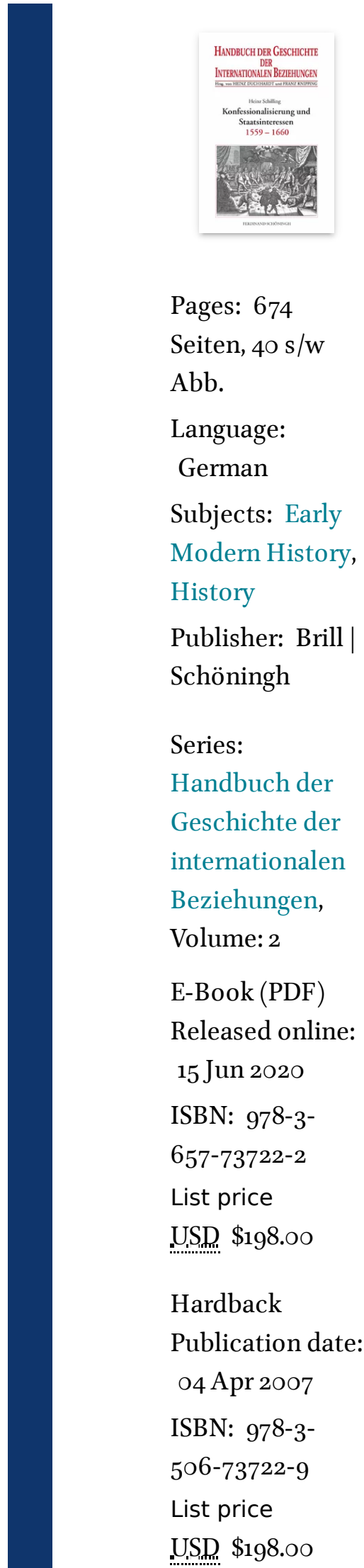


For more information see brill.com

Order information: Order online at brill.com +44330 333 0049 | customerservices@brill.com Submission information: brill.com/authors

Titles published by Brill | Fink, Brill | mentis or Brill | Schöningh: +49(o)715413279216| brill@brocom.de 